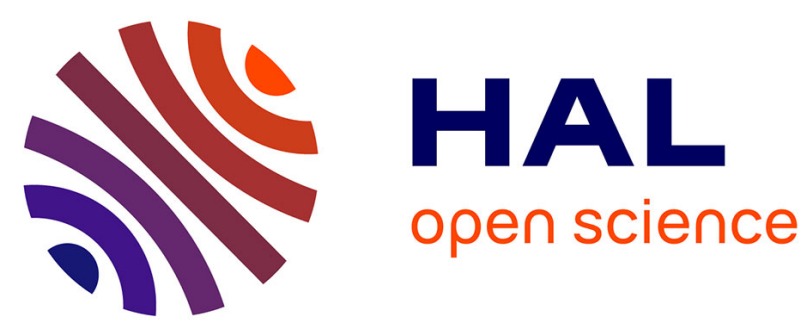

\title{
Fast Neutron Irradiated Magnetite and Haematite Investigated by Neutron Diffraction
}

\author{
S. Meillon, F. Dunstetter, H. Pascard, J. Rodriguez-Carvajal
}

\section{To cite this version:}

S. Meillon, F. Dunstetter, H. Pascard, J. Rodriguez-Carvajal. Fast Neutron Irradiated Magnetite and Haematite Investigated by Neutron Diffraction. Journal de Physique IV Proceedings, 1997, 07 (C1), pp.C1-607-C1-608. 10.1051/jp4:19971251 . jpa-00254959

\section{HAL Id: jpa-00254959 https://hal.science/jpa-00254959}

Submitted on 1 Jan 1997

HAL is a multi-disciplinary open access archive for the deposit and dissemination of scientific research documents, whether they are published or not. The documents may come from teaching and research institutions in France or abroad, or from public or private research centers.
L'archive ouverte pluridisciplinaire HAL, est destinée au dépôt et à la diffusion de documents scientifiques de niveau recherche, publiés ou non, émanant des établissements d'enseignement et de recherche français ou étrangers, des laboratoires publics ou privés. 


\title{
Fast Neutron Irradiated Magnetite and Haematite Investigated by Neutron Diffraction
}

\author{
S. Meillon, F. Dunstetter, H. Pascard and J. Rodriguez-Carvajal* \\ Laboratoire des Solides Irradiés CEA - URA 1380 du CNRS, École Polytechnique \\ 91128 Palaiseau cedex, France \\ * Laboratoire LLB, CEN Saclay, 91191 Gif sur Yvette, France
}

\begin{abstract}
In this paper, we present new experimental results about crystallographic and magnetic properties obtained on magnetite $\mathrm{Fe}_{3} \mathrm{O}_{4}$ and haematite $\alpha-\mathrm{Fe}_{2} \mathrm{O}_{3}$ samples irradiated by fast neutrons. Polycrystalline rods were irradiated at $350 \mathrm{~K}$ by fast neutrons inside the core of Melusine nuclear reactor (CENG) in Grenoble at various fluences (4 10 ${ }^{19}, 9.210^{19}$ and 20 $10^{19}$ neutrons $/ \mathrm{cm}^{2}$ ). The irradiated samples have been studied by the neutron diffraction technique. Contrary to the case of garnets ferrites, where amorphization is observed at such fluences, no similar effect is observed in magnetite : one just observes a very weak swelling. Results about haematite are also discussed.
\end{abstract}

\section{INTRODUCTION}

Investigations of the changes in crystallographic and magnetic properties of ferrites induced by fast neutron irradiation are of great interest in several fields within nuclear industry and research. Particularly relevant is to know the behaviour of ferromagnetic magnets in reactors and accelerators. The first studies of the transformation of the spinel and garnet crystallographic structure by fast neutron irradiation were reported by Podsekin et al [1], Chukalkin et al [2] and Pascard et al [3]. At low fluences, a swelling was observed. At higher fluences, either amorphization or phase transition are observed. The aim of our study is to investigate the case of magnetite and haematite.

\section{EXPERIMENTAL}

In this paper, $\mathrm{Fe}_{3} \mathrm{O}_{4}$ and $\alpha-\mathrm{Fe}_{2} \mathrm{O}_{3}$ samples were irradiated by fast neutrons in the Melusine 8-MW light-water nuclear reactor of C.E.N. Grenoble with a flux of fast neutrons $\left(E_{\mathrm{n}}>0.1 \mathrm{MeV}, \Phi=1.210^{13}\right.$ neutrons $\left.\mathrm{cm}^{-2} \mathrm{~s}^{-1}\right)$ at various fluences $\left(410^{19}, 9.2\right.$ $10^{19}$ and $2010^{19}$ neutrons $/ \mathrm{cm}^{2}$ ). Polycrystalline samples of $\mathrm{Fe}_{3} \mathrm{O}_{4}$ were synthetized using a classical ceramic method.

The neutron diffraction technique makes it possible to determine both the atomic and the magnetic structures of magnetic materials. For unpolarized neutrons, the nuclear and magnetic scattering are independent: the structure factor of any Bragg lines is just the sum of the nuclear and magnetic structure factors, without crossed term. One can just obtain the modulus of magnetic moments, since polarized neutrons are necessary to determine their orientation.

The high resolution powder diffractometer with unpolarized neutrons D1A, located at the G4 neutron guide of the Orphee reactor in Saclay, was used. The data were refined with the Rietveld method [4, 5]. The usual structures were observed without structural change. The cell parameters and magnetic moments will be discussed below.

\section{RESULTS}

$\alpha-\mathrm{Fe}_{2} \mathrm{O}_{3}$ is not a ferrimagnetic but an antiferromagnetic material and, therefore, will be presented separately.

$\alpha-\mathrm{Fe}_{2} \mathrm{O}_{3}$ : The main framework of this structure is a hexagonal close-packing of oxygen ions, in which metallic ions lie at octahedral interstices. In figure 1, we show the parameter lattice variation $\Delta \mathrm{a} / \mathrm{a}$ and $\Delta \mathrm{c} / \mathrm{c}$ of $\alpha-\mathrm{Fe}_{2} \mathrm{O}_{3}$ samples as a function of fluence. The volume swelling is about $0.5 \%$ at high fluences. The linear expansion shows an anisotropic behaviour along $c$ and a-axis. This result is coherent with the results obtained by grinding of haematite powder [6] : the observation of a direct phase transformation from haematite (hexagonal) to maghemite (f.c.c.) is also accompanied by an expansion along the c-axis of the hexagonal lattice.

The magnetic moment of the octahedral site $\left(4.0 \pm 0.2 \mu_{\mathrm{B}}\right)$ is independent of the fluence. 
$\mathrm{Fe}_{3} \mathrm{O}_{4}$ : Magnetite is the simplest among the compounds crystallizing in the spinel structure. The spinel structure consists of a cubic-close-packed cage of oxygen ions with the metallic ions occupying the tetrahedral (A) and octahedral (B) interstitial sites. In $\mathrm{Fe}_{3} \mathrm{O}_{4}$, the cations distribution is inverse, the tetrahedral (A) sites being occupied exclusively by $\mathrm{Fe}^{3+}$ ions and the octahedral (B) sites being shared by $\mathrm{Fe}^{3+}$ and $\mathrm{Fe}^{2+}$ ions in equal proportion [7].

The variation of the cell parameter $\Delta \mathrm{a} / \mathrm{a}$ is given in figure 2, compared to that of $\mathrm{YIG}$ garnet $\left(\mathrm{Y}_{3} \mathrm{Fe}_{5} \mathrm{O}_{12}\right)$ previously studied [3]. The only effect of irradiation in magnetite is a very weak swelling $(<0.1 \%$ in volume, compared to $2 \%$ for YIG observed at the highest fluence). Moreover no amorphization is observed in magnetite, contrary to the YIG garnet case [3]. The background of the diffractograms, the diffraction peak positions and the peak linewidths change hardly as a function of fluence.

The refined values of the magnetic moments located at the A and B-sites are given at table $1:$ the distribution of the magnetic moments of the iron ions in the tetrahedral and octahedral sites is not modified as a function of fluence. A possible magnetic moment on the oxygen atoms, arising from superexchange, was not considered here due to the limitations of the powder unpolarized neutron experiment.

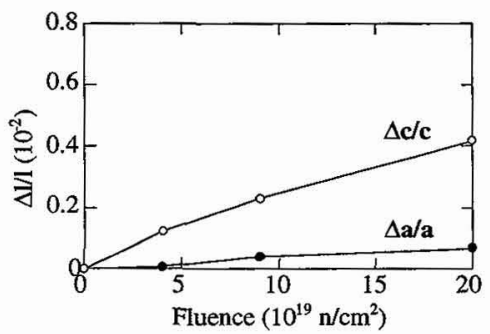

Figure 1 : Lattice parameter variation $\Delta \mathrm{a} / \mathrm{a}$ and $\Delta \mathrm{c} / \mathrm{c}$ as a function of fast neutron fluence for $\alpha-\mathrm{Fe}_{2} \mathrm{O}_{3}$ samples.

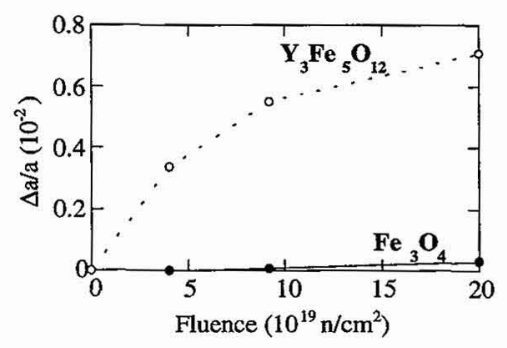

Figure 2 : Lattice parameter variation $\Delta \mathrm{a} / \mathrm{a}$ as a function of fast neutron fluence for $\mathrm{Fe}_{3} \mathrm{O}_{4}$ spinel and for $\mathrm{Y}_{3} \mathrm{Fe}_{5} \mathrm{O}_{12}$ garnet.

Table 1 : Magnetic moments localized on the different kind of sites, i.e., A-site moment occupied by $\mathrm{Fe}^{3+}$ and $\mathrm{B}$-site moment occupied by $\mathrm{Fe}^{3+}$ and $\mathrm{Fe}^{2+}$, in magnetite.

\begin{tabular}{|c|c|c|c|c|}
\hline $\mathrm{Fe}_{3} \mathrm{O}_{4}$ Samples & unirradiated & $4.10^{19} \mathrm{n} / \mathrm{cm}^{2}$ & $9.2 .10^{19} \mathrm{n} / \mathrm{cm}^{2}$ & $20.10^{19} \mathrm{n} / \mathrm{cm}^{2}$ \\
\hline $\mathrm{M}_{\mathrm{A}}\left(\mu_{\mathrm{B}}\right)$ & $3.99 \pm 0.20$ & $4.01 \pm 0.20$ & $3.89 \pm 0.19$ & $3.85 \pm 0.19$ \\
\hline $\mathrm{M}_{\mathrm{B}}\left(\mu_{\mathrm{B}}\right)$ & $3.92 \pm 0.19$ & $3.81 \pm 0.19$ & $3.80 \pm 0.19$ & $3.80 \pm 0.19$ \\
\hline
\end{tabular}

\section{DISCUSSION AND CONCLUSION}

We think that the origin of the behaviour of magnetite can be related both to the existence of octahedral and tetrahedral empty sites and the presence of two kinds of iron ions, for the following reasons : (i) the spinel structure exhibits a lot of empty sites (9 per $\mathrm{Fe}_{3} \mathrm{O}_{4}$ unit), (ii) haematite has just two empty sites per $\mathrm{Fe}_{2} \mathrm{O}_{3}$ unit and (iii) the YIG garnet has no empty site. Therefore, we think that the $\mathrm{Fe}_{3} \mathrm{O}_{4}$ spinel structure can easily accomodate the atomic displacements and the valence changes induced by irradiation and, thereby, can prevent the amorphization and limit the swelling. The case of haematite is intermediate. Further Mössbauer experiments are planned in order to check such an hypothesis (when the radioactivity will be sufficiently low for the samples to be machined).

As a conclusion we emphasize the exceptional resistance of magnetite under fast neutron irradiation, similar to the results observed with high energy heavy ion irradiation [8].

\section{References}

[1] Podsekin A. K. and Zaitsev V. N., Sov. Phys. Solid. State 24 (1982) 342-343

[2] Chukalkin Yu. G., Goshchitskii B. N., Dubinin S. F., Sidorov S. K., Petrov V. V., Parkhomenko V. D. and Vologin V. G., Phys. Stat. Sol. (a) 28 (1975) 345-354

[3] Pascard H., Globus A., Roult G. and Bacher P., American Ceramic Society Bulletin 66 (1987) 813-817

[4] Rietveld H. M., J. Appl. Cryst. 2 (1969) 65-71

[5] Rodriguez-Carvajal J., Defects and Disorder in Crystalline and Amorphous Solids (Ed. C.R.A. Catlow, Klumer Academic Publishers, 1994) Nato ASI Series C $\mathbf{4 1 8}$ pp. 137-156

[6] Meillon S., Dammak H., Flavin E. and Pascard H., Phil. Mag. Letters 72 (1995) 2 105-110

[7] Shull C. G. and Smart J. S., Phys. Rev. 76 (1949) 1256-1257

[8] Meillon S., Studer F., Hervieu M, and Pascard H., Nucl. Instr. and Meth. B 107 (1996) 363-367 